\title{
Medical students' perspectives on teaching a concise embryology course
}

This article was published in the following Dove Press journal:

Advances in Medical Education and Practice

\section{Megan Williamson \\ Charlotte Willis \\ Lucy Higgins}

Manchester Medical School, Faculty of Biology, Medicine and Health, The University of Manchester, Manchester, UK
Correspondence: Megan Williamson Faculty of Biology, Medicine and Health The University of Manchester, Oxford Road, MI 3 9PL Manchester, UK Email megan.williamson@student. manchester.ac.uk

\section{Dear editor}

We read the research article entitled "Condensing embryology teaching for medical students: can it be taught in 2 hours?" with great interest. As fourth year medical students, we appreciate their attempt to simplify embryology teaching into a "crash course". However, we feel that the course may benefit from further consideration into the most effective teaching style.

Embryology is a valued part of the medical curriculum, and students recognize the need to learn both the basic science and its clinical application., ${ }^{2,3}$ Kazzazi and Bartlett ${ }^{1}$ emphasize in their article that students do not feel that embryology teaching is effectively delivered. Yet, while their course simplifies some of the teaching and explores some clinical aspects of embryology, it is still delivered in a lecture format. Studies by Bhalli et $\mathrm{al}^{4}$ and Almigbal ${ }^{5}$ have found that the majority of medical students prefer interactive lectures, have "reflector" learning styles, and prefer a combination of visual, auditory, written, and practical learning. This suggests that interactive sessions may have better outcomes than lectures. Feedback from the course, suggesting the use of more visual aspects, supports this. Scott et $\mathrm{al}^{2}$ also found that students value case-based learning. This method could be adopted to deliver clinical teaching interactively.

Favoring a reflector learning style implies that students may benefit most from learning embryology in a variety of environments: learning basic science from experts, key examinable elements from peers, and clinical relevance from clinicians, to develop a strong, well-rounded knowledge of embryology. A study by Hamilton and Carachi ${ }^{3}$ also found that students prefer to learn core embryology early in medical school before progressing to clinical study. This may support the idea that the course provides a good step between preclinical and clinical teaching, but cannot be used independently.

In summary, we agree that concise embryology teaching, focusing on clinical application, may help to engage medical students. We suggest that the course may be improved by offering more interactive sessions, with case-based discussions, to maximize its effectiveness.

\section{Disclosure}

The authors report no conflicts of interest in this communication. 


\section{References}

1. Kazzazi F, Bartlett J. Condensing embryology teaching for medical students: can it be taught in 2 hours? Adv Med Educ Pract. 2017;8: 797-806.

2. Scott KM, Charles AR, Holland AJ. Clinical embryology teaching: is it relevant anymore? ANZ J Surg. 2013;83(10):709-712.

3. Hamilton J, Carachi R. Clinical embryology: is there still a place in medical schools today? Scott Med J. 2014;59(4):188-192.

4. Bhalli MA, Khan IA, Sattar A. Learning style of medical students and its correlation with preferred teaching methodologies and academic achievement. J Ayub Med Coll Abbottabad. 2015;27(4):837-842.

5. Almigbal TH. Relationship between the learning style preferences of medical students and academic achievement. Saudi Med J. 2015;36(3):349-355. 


\section{Authors' reply}

\section{Fawz Kazzazi \\ Jonathan Bartlett}

School of Clinical Medicine, University of Cambridge, Cambridge, UK

Correspondence: Fawz Kazzazi

School of Clinical Medicine, University of Cambridge, 37 Grange Road, Leckhampton House, Cambridge CB2 IRH, UK

Tel +4477542 2005

Email fk276@cam.ac.uk

\section{Dear editor}

We are very glad to see that our initial work has engaged so many medical students to come forward to reflect on embryology teaching. The foundation of Williamson et al's letter surrounds the already highly debated topic of teaching delivery. In the first instance, our work was designed to clearly and easily explain the embryology curriculum to medical students in a timely manner that reflected the topic's total proportion of the medical degree - the key reasons for students neglecting it (difficulty and insignificance).

Williamson et al implored us to seek the "most effective teaching style", while recommending that a "reflector"style approach will be the solution to this. We agree that embryology should act as a key proponent of a medical curriculum, with great value on reflection in the clinical parts of the degree. However, we would like to reiterate that this was a course designed to teach and explain the embryological curriculum as per the students' future examinations. There was extensive use of clinical information to allow students to appreciate the application of this information in their careers. This prepares the student to engage in "reflector" learning when they engage with embryology in other environments. The reflector techniques proposed by the authors are very resource intensive, require high human capital, and very strong collaboration/clarity across different persons.

Furthermore, the evidence base proposed by Williamson et al for use of reflector teaching styles is poor. In that study, ${ }^{1}$ less than half of 77 students stated that they preferred "reflective style" teaching. There also exists evidence to show that the learning style does not influence the results of the medical students, which adds to the case that this is a heavily debated and misunderstood field. ${ }^{2}$

The value of clinical application is tremendous, as it contextualizes the teaching to the vocation. However, when designing a homogenous course for multiple universities, it is difficult to propose cases due to the additional teaching that would be required; for example, intrepretation of clinical tests and results.

We will reflect on the feedback provided and look to improve this course. We would ensure that we meet all types of teaching styles as a priority in the next iteration of course design and delivery, and this is an exciting challenge. We hope that the authors carry forward their enthusiasm to teach embryology in the final year of their degree. We will react to the responses from peers to continue to further develop this course and implement changes when delivering at multiple institutions in the future.

\section{Disclosure}

The authors report no conflicts of interest in this communication.

\section{References}

1. Bhalli MA, Khan IA, Sattar A. Learning style of medical students and its correlation with preferred teaching methodologies and academic achievement. J Ayub Med Coll Abbottabad. 2015;27(4):837-842.

2. Wilkinson T, Boohan M, Stevenson M. Does learning style influence academic performance in different forms of assessment? J Anat. 2014;224(3):304-308.

\footnotetext{
Dove Medical Press encourages responsible, free and frank academic debate. The content of the Advances in Medical Education and Practice 'letters to the editor' section does not necessarily represent the views of Dove Medical Press, its officers, agents, employees, related entities or the Advances in Medical Education and Practice editors. While all reasonable steps have been taken to confirm the content of each letter, Dove Medical Press accepts no liability in respect of the content of any letter, nor is it responsible for the content and accuracy of any letter to the editor.
}

Advances in Medical Education and Practice

\section{Publish your work in this journal}

Advances in Medical Education and Practice is an international, peerreviewed, open access journal that aims to present and publish research on Medical Education covering medical, dental, nursing and allied health care professional education. The journal covers undergraduate education, postgraduate training and continuing medical education

\section{Dovepress}

including emerging trends and innovative models linking education, research, and health care services. The manuscript management system is completely online and includes a very quick and fair peer-review system. Visit http://www.dovepress.com/testimonials.php to read real quotes from published authors. 